\title{
SISTEM PENUNJANG KEPUTUSAN MENENTUKAN PILIHAN ASURANSI INVESTASI MENGGUNAKAN METODE PERBANDINGAN EKSPONENSIAL
}

\author{
Mohammad Irwan Ukkas ${ }^{1)}$, Ekawati Yulsilviana ${ }^{2)}$, Muhamad Ghafur ${ }^{3)}$ \\ ${ }^{1,3)}$ Teknik Informatika, STMIK Widya Cipta Dharma \\ ${ }^{2)}$ Manajemem Informatika, STMIK Widya Cipta Dharma \\ ${ }^{1,2,3)}$ J1. Prof. M Yamin No.25, Samarinda, 75123 \\ E-Mail : irwan212@yahoo.com ${ }^{1)}$, ekawicida@gmail.com ${ }^{2)}$, ghofur36@gmail.com ${ }^{1)}$
}

\begin{abstract}
ABSTRAK
Sistem penunjang keputusan menentukan asuransi investasi terbaik dibangun dikarnakan kurangnya pengetahuan tentang perhitungan perbandingan investasi dan kriteria - kriteria untuk perbandingan antar asuransi yang terbaik bagi calon nasabah, dan dengan begitu banyaknya perusahaan Asuransi yang ada, banyak juga penawaran yang berbeda beda. Dalam penelitian ini, teknik pengumpulan data yang digunakan adalah studi pustaka, studi lapangan, observasi dan wawancara.

Metode Pengembangan Sistem yang digunakan pada sistem penunjang keputusan perbandingan asuransi investasi terbaik, menggunakan metode pengembangan sistem Waterfall dengan melakukan penelitian dan perancangan sistem, Dengan menggunakan Metode Waterfall sistem yang dibuat untuk membantu dalam pengambilan keputusan calon nasabah.

Hasil dari penelitian ini adalah dibuatnya sistem penunjang keputusan untuk mengetahui perbandingan asuransi terbaik berdasarkan hasil penilaian. Pengguna yang telah dilakukan Pengujian sistem menggunakan pengujian White Box dan pengujian Beta, dan dapat disimpulkan sistem yang dibuat telah sesuai dan kedepannya dapat dikembangkan kembali. Setelah sistem sesuai dengan menampilkan nilai hasil terbaik, maka sistem tersebut akan menampilkan keputusan.
\end{abstract}

Kata Kunci : Sistem Penunjang Keputusan, Metode Perbandingan Eksponensial, Asuransi Investasi

\section{PENDAHULUAN}

Dengan kurangnya pengetahuan tentang perhitungan perbandingan investasi dan kriteria - kriteria untuk perbandingan antar asuransi yang terbaik bagi calon nasabah, dan dengan begitu banyaknya perusahaan Asuransi yang ada, banyak juga penawaran yang berbeda beda. selaku calon Nasabah Asuransi selalu ingin mengetahui sendiri hitungan perbandingan mulai dari bunga pehitungan jangka waktu sampai nominal yang harus disetor perbulan maupun pertahun, terkadang agen atau yang mengajak calon Nasabah masuk suatu prusahaan Asuransi akan menjelaskan perhitungannya tetapi terkadang juga bagi Calon Nasabah akan kesulitan memahaminnya dan kebanyakan tergiur dengan perhitungan tersebut.

Untuk melakukan perbandingan dan meningkatkan pengetahuan maka memerlukan suatu metode sistem penunjang keputusan sehingga mudahnya mengetahui kelebihan maupun kekurangan investasi di suatu prusahaan asuransi, setelah mengetahui pebandingan dapat menentukan pilihan lebih mudah, tetapi dengan memutuskan pilihan secara pasti bisa dengan mengetahui keseluruhan fungsi dari aspek - aspek penilaian ataupun kriterian dari asuransi investasi tersebut, banyak hal juga yang ikut mempengaruhi penilaian dari setiap kriteria tersebut antara lain menurut beberapa calon nasabah dan beberapa agen yang menawarkan asuransi tersebut.

Menyadari permasalahan di atas, maka dibuat suatu sistem sebagai solusi bagi terwujudnya pemanfaatan waktu semaksimal mungkin serta mengurangi tingkat kesalahan terutama dalam perhitungan Hasil Investasi dengan membuat suatu aplikasi berbasis komputer untuk menghitung perbandingan investasi pada asuransi. Sesuai dengan peraturan yang sudah ditentukan oleh pihak perusahaan asuransi untuk calon nasabahnya, maka diperlukan faktor - faktor untuk mengetahui perhitungan investasi. Berdasarkan permasalahan di atas, maka akan dibuat sebuah sistem dengan judul "Sistem Penunjang Keputusan Menentukan Pilihan Asuransi investasi yang Sesuai keinginan dan Terbaik Menggunakan Metode Perbandingan Eksponensial (MPE)".

Dari keputusan yang mudah diambil, dan juga keputusan yang baru dapat diambil setelah dipertimbangkan segala macam aspek secara cermat, ada keputusan yang hasilnya hanya membawa konsekuensi bagi pihak yang mengambil keputusan tersebut, ada juga keputusan yang menyangkut nasib orang banyak. Sedangkan Sistem pendukung keputusan itu sendiri merupakan bagian dari sistem informasi berbasis komputer (termasuk sistem berbasis pengetahuan/manajemen pengetahuan) yang dipakai untuk mendukung pengambilan keputusan dalam suatu organisasi atau perusahaan. Dapat juga dikatakan sebagai sistem komputer yang mengolah data menjadi informasi untuk mengambil keputusan dari masalah semiterstruktur yang spesifik. Dengan menggunakan sebuah aplikasi sebagai pendukung dalam melakukan sebuah pekerjaan dapat memudahkan dan meminimalisir waktu yang ada. Dengan adanya sebuah aplikasi sebagai pendukung dalam melakukan sebuah pekerjaan maka keputusan yang dihasilkan lebih akurat dan cepat.

\section{RUANG LINGKUP PENELITIAN}

Mengingat luasnya ruang lingkup permasalahan yang ada dan menghindari berkembangnya pembahasan tentang 
sistem maka penulis menentukan batasan masalah yang akan diteliti adalah dihalaman berikutnya:

1. Hanya membahas Asuransi yang terdapat investasi

2. Tabel penentuan nilai Ordinal di setiap kriteria sudah ditentukan sistem

3. Penentuan bobot atau skala ordinal sudah ditentukan sistem

4. Sistem yang dibuat merupakan penunjang keputusan saja, sehingga keputusan sesungguhnya yang diambil tetap berada pada pihak calon nasabah dengan menetukan sendiri keputusannya.

5. Adapun kriteria penilaian dalam pemilihan produk asuransi meliputi : santunan, brand image, kinerja keuangan, proses klaim, premi,bunga dan daftar penyakit kritis yang ditanggung.

6. Laporan untuk aplikasi sistem pengambilan keputusan pemilihan produk asuransi ini adalah, grafik perbandingan perkriteria dan laporan grafik nilai keseluruhan atau peringkat.

\section{BAHAN DAN METODE}

Adapun bahan dan metode algoritma yang digunakan dalam sistem ini adalah :

\subsection{Sistem Pendukung Keputusan}

Salah satu jenis sistem aplikasi yang sangat popular dikalangan manajemen perusahaan adalah Sistem Penunjang Keputusan. Sistem Penunjang Keputusan ini merupakan suatu informasi yang diharapkan dapat membantu manajemen dalam proses pengambilan keputusan. Hal yang perlu ditekankan disini adalah bahwa keadaaan Sistem Penunjang Keputusan bukan untuk menggantikan keputusan, tetapi untuk menjadi sasaran penunjang bagi mereka.

\subsection{Tujuan dari Sistem Pendukung Keputusan}

Tujuan dari sistem Penunjang keputusan menurut Turban (2005):

1. Membantu seorang pemimpin dalam pengambilan keputusan atas masalah semi terstruktur.

2. Memberikan dukungan atas pertimbangan pemimpin dan bukannya dimaksudkan untuk menggantikan seorang pemimpin.

3. Meningkatkan efektifitas keputusan yang diambil pemimpin lebih dari pada perbaikan efisiensinya

4. Kecepatan Komputasi. Komputer memungkinkan para pengambil keputusan untuk melakukan banyak komputasi secara cepat dengan biaya rendah.

5. Peningkatan efektifitas. Membangun satu kelompok pengambilan keputusan, terutama para pakar, bisa mahal. Pendukung terkomputerisasi biasa mengurangi ukuran kelompok dan memungkinkan para anggota untuk berada di berbagai lokasi yang berbeda-beda.

6. Dukungan kualitas. Komputer bisa meningkatkan kualitas keputusan yang di cabut.

7. Berdaya asing. Manajemen dan pemberdayaan sumber daya perusahaan.

8. Mengatasi keterbatasan kognitif dalm pemrosesan dan penyimpanan.

\subsection{Asuransi Jiwa}

Menurut Aruan (2014) Asuransi Jiwa ialah, pelimpahan resiko atas kerugian berupa keuangan oleh tertanggung kepada pihak penanggung. Resiko dari pihak tertanggung tersebut kepada penanggung bukanlah resiko atas hilangnya jiwa,akan tetapi merupakan kerugian berupa keuangan sebagai ganti rugi hilangnya jiwa seseorang atau karena dengan alasan umur sehingga tidak produktif.

\subsection{Kriteria Pemilihan}

Ada beberapa kristeria yang dipakai dalam penelitian ini, dijabarkan sebagai berikut:

1. Santunan : sejumlah uang yang wajib dibayar oleh penanggung kepada penikmat dalam hal meninggalnya tertanggung sesuai dengan kesepakatan yang tercantum dalam polis. Penikmat yang di maksud adalah orang yang ditunjuk oleh tertanggung atau orang yang menjadi ahli warisnya sebagai yang berhak menerima dan menikmati santunan sejumlah uang yang dibayar oleh penanggung. Pembayaran santunan merupakan akibat terjadinya peristiwa, yaitu meninggalnya tertanqgung dalam jangka waktu berlaku asuransi jiwa.

2. Brand Image : merupakan representasi dari keseluruhan persepsi terhadap merek dan dibentuk dari informasi dan pengalaman masa lalu terhadap merek itu. Citra terhadap merek berhubungan dengan sikap yang berupa keyakinan dan preferensi terhadap suatu merek.

3. Kinerja Keuangan : digunakan sebagai salah satu dasar untuk memprediksi laba bersih dan dividen pada masa yang akan datang. Cara yang digunakan untuk mendukung prediksi tersebut adalah dengan menganalisis laporan keuangan perusahaan.

4. Proses Klaim : dalam istilah asuransi diartikan sebagai permintaan atau tuntunan pembayaran manfaat sesuai dengan ketentuan yang diatur dalam polis asuransi.

5. Premi : adalah sejumlah uang yang wajib dibayar oleh tertanggung kepada penanggung setiap jangka waktu tertentu, biasanya setiap bulan selama asuransi berlangsung. Besarnya jumlah premi asuransi tergantung pada jumlah asuransi yang disetujui oleh tertanggung pada saat diadakan asuransi.

\subsection{Skala Likert}

Menurut Widoyoko (2012) prinsip pokok skala likert adalah menetukan lokasi kedudukan seseorang dalam suatu kontinum sikap terhadap objek sikap, mulai dari sangat negetif sampai dengan sangat positif. Skala likert adalah suatu skala psikometrik yang digunakan dalam kuesioner dan merupakan salah satu teknik yang dapat digunakan dalam evaluasi suatu program atau kebijakan perencanaan 
untuk mengukur sikap, pendapat dan persepsi seseorang atau sekelompok orang tentang kejadian atau gejala sosial.

\subsection{Multifactor Evaluation Process (MFEP)}

Metode perbandingan eksponensial (MPE) merupakan salah satu metode pengambilan keputusan yang mengkuantifikasikan pendapat seseorang atau lebih dalam skala tertentu. Pada prinsipnya ia merupakan metode skoring terhadap pilihan yang ada. Dengan perhitungan secara eksponensial, perbedaan nilai antar kriteria dapat dibedakan tergantung kepada kemampuan orang yang menilai.

Langkah-langkah yang perlu dilakukan dalam pemilihan keputusan dengan MPE adalah :

1. Penentuan alternatif keputusan

2. Penyusunan kriteria keputusan yang akan dikaji

3. Penentuan derajat kepentingan relatif setiap kriteria keputusan dengan menggunakan skala konversi tertentu sesuai keinginan pengambil keputusan

4. Penentuan derajat kepentingan relatif dari setiap alternatif keputusan, dan

5. Pemeringkatan nilai yang diperoleh dari setiap alternatif keputusan

Formulasi penghitungan total nilai setiap pilihan keputusan adalah sebagai berikut:

$$
\text { Total Nilai }\left(T N_{i}\right)=\sum_{j=1}^{m}\left(V_{i j}\right)^{B_{j}}
$$

dimana:

Tni $=$ Total Nilai Alternatif Ke-

Vij = derajat kepentingan relatif kriteria ke-j pada keputusan ke-i, yang dapat dinyatakan dengan skala ordinal $(1,2,3,4,5)$

$\mathrm{Bj}=$ derajat kepentingan kriteria keputusan, yang dinyatakan dengan bobot

$\mathrm{m}=$ jumlah kriteria keputusan

\section{RANCANGAN SISTEM}

Berikut ini adalah flowchart Sistem Pendukung keputusan pemilihan produk asuransi :

\subsection{Flowchart Sistem Pemilihan Produk Asuransi}

Pada flowchart sistem admin mengimputkan data faktor, data perusahaan asuransi kemudian admin melakukan proses perhitungan, setelah itu mencetak laporan.

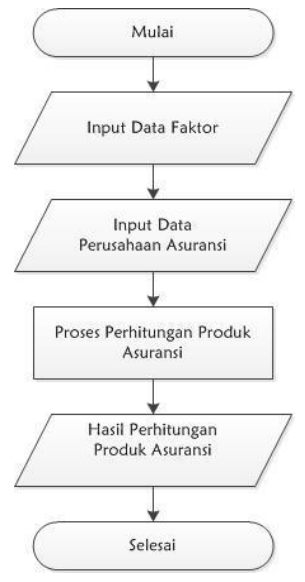

Gambar 1. Flowchart Sistem

\subsection{Flowchart Multifactor Evaluation Process}

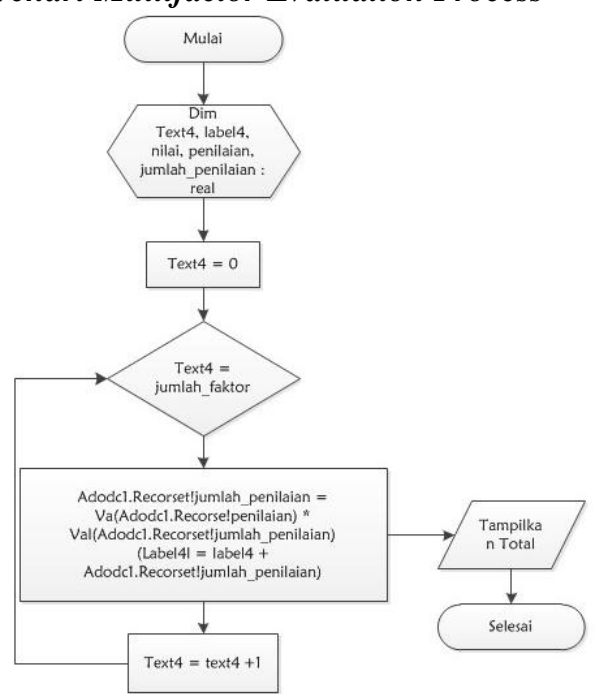

Gambar 2. Flowchart Multifactor Evaluation Process

\section{5. IMPLEMENTASI}

Hasil implementasi berdasarkan analisis dan perancangan adalah sebagai berikut:

1.1 1. Form Input Asuransi

Form ini berfungsi untuk menambah data asuransi

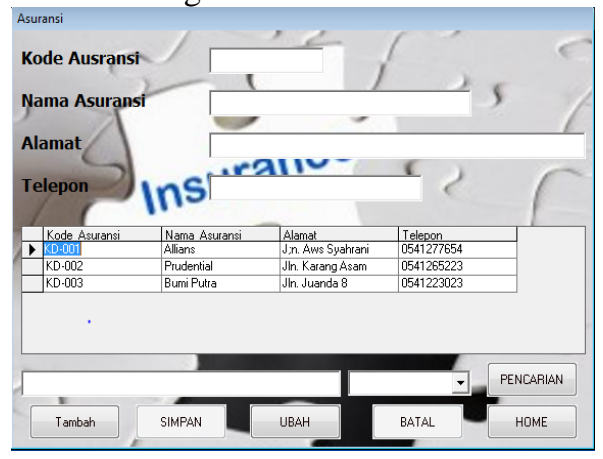

Gambar 3. Form data Faktor

1.2 2. Form Proses Kriteria

Form ini berfungsi untuk mengubah nilai bobot dari kriteria yang digunakan.

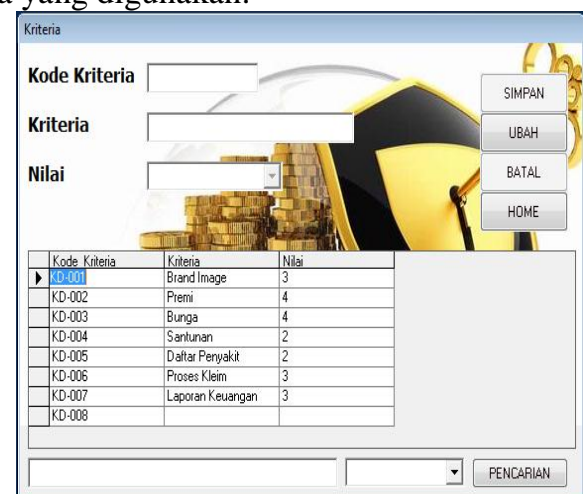

Gambar 4. Form tampilan proses penilaian perusahaan asuransi

3. Form MPE

Form ini adalah hasil dari proses penilaian 


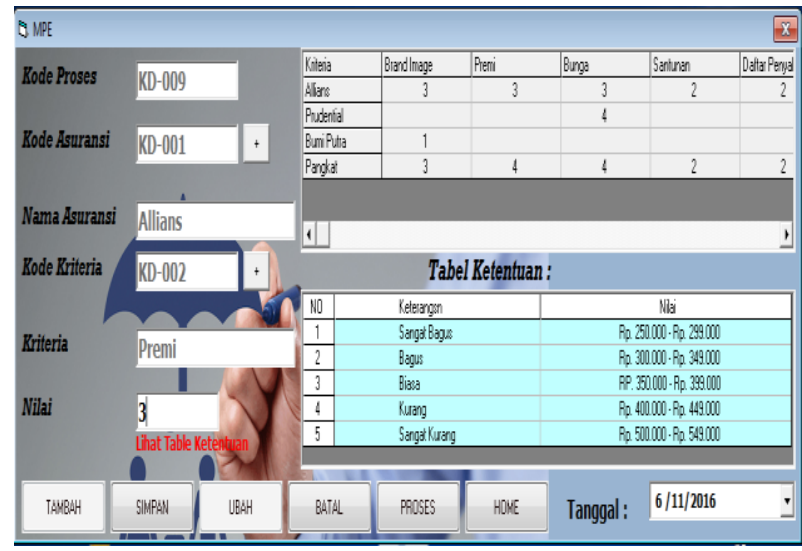

Gambar 5. Form Hasil Penilaian

\section{Tampilan Laporan Grafik Keseluruhan}

Di bawah ini adalah tampilan Laporan grafik Keseluruhan pada spk menentukan pilihan asuransi investasi yang sesuai keinginan dan terbaik menggunakan metode perbandingan eksponensi

\section{Laporan Grafik Keseluruhan}

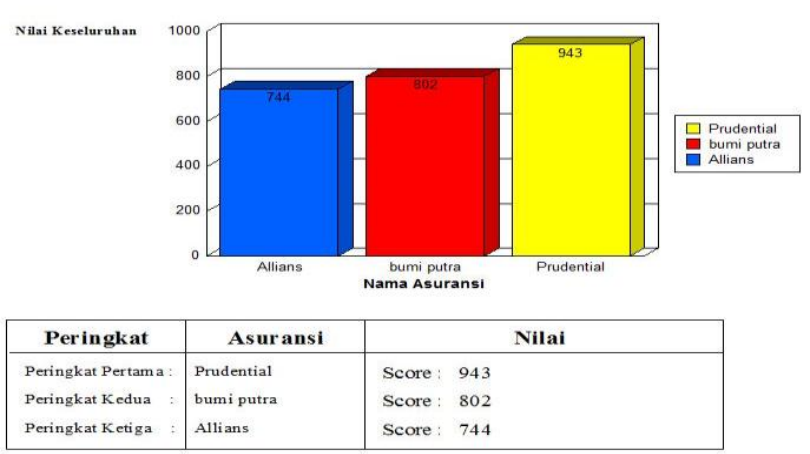

Gambar 6. Tampilan Laporan Grafik Keseluruhan

\section{KESIMPULAN}

Dari hasil penelitian dan pembahasan yang dilakukan, maka dapat ditarik kesimpulan sebagai berikut:

1. Metode Perbandingan Eksponensial (MPE) diterapkan dalam sistem pendukung keputusan, untuk menghitung serta memberikan hasil akhir penilaian yang telah dirankingkan sehingga dapat menentukan perusahaan asuransi yang terpilih.

2. Metode Pengembangan Sistem menggunakan Waterfall Software dangan lima tahapan sehingga sistem yang dibuat bisa akurat.

3. Sistem pendukung keputusan ini memiliki faktor-faktor yang dapat dirubah bobot nilainya secara dinamis, dengan patokan pada tabel ketentuan dan dapat menambahkan faktor sesuai yang dibutuhkan atau secara quisioner.
Berdasarkan kesimpulan diatas, maka penulis ingin menyampaikan beberapa saran sebagai berikut:

1. Sistem penunjang keputusan pemilihan produk asuransi dengan Metode Perbandingan Eksponensial (MPE) dapat dikembangkan lagi dalam sistem berbasis web/online sehingga penerapanya juga akan lebih beragam dan dapat digunakan untuk ruang lingkup masyarakat yang lebih luas.

2. Sistem pendukung keputusan pemilihan produk asuransi dapat dikembangkan dengan metode selain MPE, misalnya seperti metode MEEP,SAW, WP, AHP, TOPSIS, dll.

3. Diharapkan agar dapat menjadi sumber referensi dan bahan pembelajaran untuk melakukan penelitian dengan objek berbeda tidak hanya pada pemilihan asuransi investasi.

4. Sistem ini seharusnya dikembangkan dan perlu ditambah dengan informasi yang lebih akurat dan jelas sehingga sistem seperti ini dapat dipergunakan perusahaan manapun yang belum pernah menggunakan asuransi.

5. Agar lebih akurat Disarankan Sistem ini seharusnya dikembangkan dengan lebih banyaknya responden yang memberikan jawaban dan lebih dari 30 responden lebih baik

\section{8. DAFTAR PUSTAKA}

9.

Al Fatta, H. 2007. Analisis \& Perancangan Sistem Informasi. Andi : Yogyakarta.

Aruan,A.2014. Sistem Pendukung Keputusan Pemilihan Asuransi Jiwamenggunakan Metode Fuzzy Multi Criteria Decision Making. Pelita Informatika Budi Darma 3(VII): 13

Bank Indonesia No. 10/10 PBI/2008 tentang penyelesaian pengaduan nasabah pasal 1 angka 2 yang dimaksud dengan nasabah atau mitra adalah pihak yang menggunakan jasa bank

Jogiyanto, HM. 2008. Sistem Teknologi Informasi Edisi III, Yogyakarta : Andi.

Khaidir,A, 2014,"Sistem Pendukung Keputusan Penyeleksian Calon Siswa Baru di SMA N 1 Badar Dengan Metode MFEP",JurnalPelita Informatika Budi Darma, Vol.5, No.3, hal.148-153,ISSN : 23019425, Medan

Kusrini, 2007, Konsep dan Aplikasi Sistem Pendukung Keputusan. Yogyakarta : Andi

Kusrini, Mukhsin, A. 2007. Sistem Pendukung Keputusan. Penerbit Gava Media, Jakarta.

Linda Atika dkk 2012, Metode Perbandingan Eksponensial (MPE) merupakan salah satu metode untuk menentukan urutan prioritas alternatife keputusan dengan kriteria jamak

Rosnani, G. 2014.Sistem Pendukung Keputusan. USU Press: Medan.

Turban E, Aronson, J E, Liang, T P , 2007. Decision Support and Business Intelligence System. 8Th edition, Pearson Education International, 52-75.

\section{SARAN}

